\title{
Revitalisering af inuitisk tradition i Grønland
}

\section{Etnopartikulær nichereligion eller New Age-tendens med globalt udsyn}

\author{
SIDSE BIRK JOHANNSEN
}

\begin{abstract}
The revitalization process among indigenous people on the North American continent has been increasing since the beginning of the 20th century, especially after 1960 (Paldam 2017, 136 Fonda 2012, 172, Wallace 1956). In Greenland, there are examples of cultural revitalization dating back to the 1970s, but interest in Inuit culture and religion has especially increased over the past decade (Krutak 2014, 55 Pedersen 2014, 51). The purpose of this paper is to clarify the differences and variations of where and how the flourishing of Inuit traditions is expressed in today's Greenlandic society. The paper highlights variations and differences between mainstream culture and niche religiosity and presents a model for categorizing different groupings in the field. Finally, the revitalization process is discussed as respectively an ethno particular niche religion or a New Age tendency with a global outlook.
\end{abstract}

DANSK RESUME: Revitaliseringstendensen blandt oprindelige folk har været stigende på det nordamerikanske kontinent siden begyndelsen af 1900-tallet og særligt efter 1960 (Paldam 2017, 136; Fonda 2012, 17, Wallace 1956). I Grønland findes der eksempler på kulturel revitalisering tilbage til 1970'erne; men opblomstringen af inuitiske traditioner og religion er særligt højnet det seneste årti (Krutak 2014, 55; Pedersen 2014, 51). Denne artikels formål er at tydeliggøre de forskellige variationer af, hvor og hvordan opblomstringen af inuitiske traditioner kommer til udtryk i nutidens grønlandske samfund. Artiklen fremhæver variationer og forskelle imellem mainstreamkultur og nichereligiøsitet og præsenterer en model til kategorisering af forskellige grupperinger $i$ feltet. Afsluttende diskuteres revitaliseringsprocessen som henholdsvis etnopartikulær nichereligion eller New Age-tendens med globalt udsyn. 
KEYWORDS: Inuit religion; indigenous revitalization; ethnic identity formation; ethno particular religion; New Age tendency; drum dance; traditional tattooing

\section{Undersøgelsesstrategi}

Revitaliseringen af inuitisk tradition forekommer alle steder, hvor inuitternes efterkommere lever i dag, hvilket hovedsageligt er de arktiske områder og Danmark (Krutak 2014, 55). Denne artikel beskriver imidlertid grundet begrænsede dataindsamlingsmuligheder udelukkende grønlandske og danske forhold. Empirien i denne undersøgelse udgøres af et todelt datasæt bestående dels af tre kvalitative, semistrukturerede interviews, dels af arkivmateriale i form af bøger, avisartikler, tv-programmer, sangtekster, platforme på sociale medier samt hjemmesider fra to moderne shamaner af grønlandsk oprindelse bosiddende i Europa. Alle individer i datasættet anses i artikel som informanter. Shamanerne trækker på mytologisk materiale fra inuitisk religion og fortælletradition og overleveringer vedrørende trommedansens rituelle funktioner. De tre informanter i den kvalitative undersøgelse er udvalgt på baggrund af deres offentlige engagement i revitaliseringen af inuitisk religion. Informanterne virker således alle $\mathrm{i}$ et eller flere aspekter inden for revitaliseringstendensen som eks. praksisser omkring trommedans, tatovering eller fortælletradition. Hele datasættet er indsamlet i efteråret 2018 og foråret 2019. Nærværende artikel er således formuleret på baggrund af en eksplorativ feltundersøgelse, som dækker dele af den inuitiske revitaliseringsproces i Grønland.

De kvalitative interviews er indsamlet af undertegnede og elever fra Nordgrønlands Gymnasiale Skole (GUX Aasiaat). Eleverne har deltaget i feltarbejdet som en del af religionsundervisningen i forbindelse med mit arbejde som gymnasielærer. Dele af interviewmaterialet er indsamlet på grønlandsk og siden oversat til dansk af eleverne selv, mens andet er indsamlet på dansk. Jeg er bevidst om faldgruberne ved sprogbarrierer og oversættelsesvanskeligheder, men jeg mener, at de opvejes af de døre, som samarbejdet med eleverne åbner $\mathrm{i}$ forhold til informanternes velvilje til at deltage $\mathrm{i}$ projektet. Alle eksempler og citater fra interview, som anvendes til underbygning af undersøgelsens konklusioner, er anonymiseret af hensyn til informanterne.

I artiklen anvendes begrebet revitaliseringstendens til at beskrive den bevidste, men løst organiserede bevægelse blandt nulevende inuit i Grønland og Danmark, som forsøger at genskabe en tradition og selvforståelse, der kulturelt hænger mere sammen med den prækoloniale kultur i Grønland (Paldam 2017, 11). Artiklen er således på linje med Anthony Wallaces beskrivelse af revitaliseringsbegrebet i "Revitalisation Movements" (Wallace 1956). I denne artikel skelner jeg mellem historisk inuit, nutidige inuit og grønlændere. Nutidige inuit er den nulevende befolkning, der etnisk og genetisk stammer fra de historiske inuit, mens 'grønlændere' betegner en nationalitet og ikke en etnicitet. ${ }^{1}$

\footnotetext{
${ }^{1}$ Grupperingerne nutidige inuit og grønlændere kan være sammenfaldende, men er det ikke nødvendigvis.
} 


\section{Inuitisk religion i fortiden}

Inuitisk religion tilhører den religionstype, som Roberth Bellah betegner som tribale religioner, også kaldet oprindelige folks religion. Inuitterne levede som nomader, og religionen var en mundtligt båret tradition (Lundager Jensen 2013, 11; Kleivan \& Sonne 1985, 3). Som med alle andre oprindelige folk gælder det, at de tekstlige kilder, vi har i dag, er indsamlet af missionærer og opdagelsesrejsende, som derfor repræsenterer et etic perspektiv med en svingende grad af objektivitet. De fleste kilder til inuitisk mytologi er indsamlet i perioden 1700-1930 af missionærer som Hans Egede og opdagelsesrejsende som Knud Rasmussen. På trods af den kulturhistoriske bias danner kilderne en solid tekstsamling, hvorfor vi ved forholdsvis meget om de gamle inuitters religion og traditioner.

Igennem myter og sagn beskrives inuitisk religion som et polyteistisk-animistisk med et dualistisk verdensbillede. Kosmos består af den synlige verden, hvor menneskerne bor, og den usynlige, besjælede parallelverden, som kun åndemaneren har adgang til. Dette hænger sammen med en meget udbredt animismetanke, hvor alt - mennesker, dyr, planter, værktøj, søvn, latter osv. - har en sjæl. Denne besjæling kaldes for inua, som betyder "manden i [tingen]". Respekten for altings inua er afgørende for opretholdelsen af balancen mellem den synlige og usynlige verden. Alt, hvad inuitterne gjorde, var bundet op på at opretholde balancen mellem disse to verdener, idet en forskudt balance var ensbetydende med sult, sygdom og død (Kleivan \& Sonne 1985, 6). Man opretholdt balancen ved at respektere guddommene, hvoraf de vigtigste var Havets Moder og Månemanden, som hersker over henholdsvis havdyr og landdyr.

Myten om Havets Moder handler kort fortalt om en pige, som mod sin vilje narres til at gifte sig med en kragelignede mand. Da hendes far forsøger at redde hende, blæser kragemanden en storm op omkring deres båd. I desperation smider faren pigen over bord og hugger hendes fingre af, da hun klamrer sig til rælingen. Pigen synker til bunds og bliver til Havets Moder. Fra hendes afhugne fingerspidser stammer alle havets dyr (Rasmussen 1925, bind 1 83-86). Når inuit ikke overholder tabureglerne, bliver Havets Moders hår filtret og beskidt, og fangstdyrene sætter sig fast i det, hvorfor der vil forekomme misfangst. Sker det, må åndemaneren foretage en ånderejse ned til Havets Moder og hjælpe hende med at rede hendes hår, så hungersnøden på bopladsen kan ophøre (ibid. 1978, bind 1, 97-98).

Inuit skulle overholde en lang række taburegler, udføre ritualer samt fremstille og bære amuletter for at opretholde balancen mellem de to verdener (ibid. 7). Trommeog maskedans har været anvendt både til rituel brug såvel som underholdningsformål. I den rituelle praksis har trommedansen været central i forhold til åndemanerens ånderejser, idet trommedansen bringer shamanen i en trancetilstand og hidkalder hans hjælpeånder (ibid. Bind 1 16, bind 2 31). Inuit kvinderne bar tatoveringer, som fungerede som fangstamuletter, der sikrede balancen mellem den synlige og usynlige verden. Tatoveringerne fungerer endvidere som et diakritisk tegn, der viser geografisk og socialt tilhørsforhold og position i samfundet (Kleivan \& Sonne 1985, 5, 17; Hansen, Meldgaard \& Nordquist 1992, 111-14 Krutak 2014, 24, 35). Mange af disse traditioner 
forsvandt med kristendommens indførelse i Grønland, særligt tabureglerne, den animistiske tankegang, tatoveringspraksissen samt tromme- og maskedans (Hansen, Meldgaard og Nordquist 1992, 109).

\section{Revitalisering af inuitiske traditioner}

Revitaliseringsprocessen blandt nutidige inuitter finder sted på flere forskellige niveauer og med forskellig tilknytning til de historiske inuitters kulturelle og religiøse traditioner. Overordnet kan revitaliseringen i Grønland inddeles i to hovedtyper som henholdsvis mainstream- og nichetendens. I nedenstående afsnit vil de to tendenser blive belyst.

\section{Revitalisering som mainstream - hvad er det, og hvor finder vi den?}

I det følgende afsnit vil forskellige mainstream-revitaliseringstendenser blive belyst, heriblandt grønlandsk modedesign, populærmusik, litteratur og hudplejeprodukter. Fælles for mainstream-revitaliseringstendensen er, at den er centreret omkring et produkt, der har afsender/producent og en modtager/køber. De forskellige afsendere når bredt ud i offentligheden, og mange mennesker har kendskab til og køber produkterne både i Grønland og Danmark. Mainstreamtendensen tager udgangspunkt i inuitisk tradition og grønlandsk natur, men forholder sig frit og afslappet til traditionen og tilpasser den til nutidige forhold og behov.

De seneste 20 år har en opblomstring af grønlandsk designet modetøj fundet sted. Blandt de toneangivende modeproducenter kan nævnes Isaksen Design (grundlagt 2002), Bibi Chemnitz (grundlagt 2006) og Nuuk Couture (grundlagt 2010). Modeproducenterne lader sig inspirere af grønlandsk kultur og natur i forbindelse med pasform, grafisk udtryk og valg af materiale, hvilke de tydeligt giver udtryk for gennem interviews, hjemmesider og platforme på sociale medier:

Vi henter inspiration fra vores grønlandske baggrund og blander disse med kosmopolitiske udtryk fra den internationale modescene (Nickie Isaksen, Isaksen Design, til Suluk 2019, nr. 1).

Der findes mange forskellige eksempler på inspirationen fra den oprindelige kultur i nutidens modetøj (Pedersen 2014, 53). Blandt andet kan nævnes den grafiske redigering af nationaldragtens mønstre i halskraven samt snit og pasform, der er inspireret af klædedragter fra arkæologiske fund. Forskellige tatoveringsmotiver bruges desuden af både Chemnitz, Isaksen Design og smykkefirmaet PanikPanik, som laver ringe og armbånd. Motiverne har rødder i den inuitiske tatoveringstradition, men bliver anvendt vidt forskelligt. I den forbindelse er det særligt interessant at fremhæve, at tatoveringernes placering i nogle tilfælde er overensstemmende med den oprindelige tatoveringspraksis som f.eks. omkring hånd- og fingerled. I de fleste tilfælde er der dog tale om et enkelt symbol, som er kopieret og omfortolket som grafisk design med det samme symbol i forskellige vinkler. 
De bruger ligesom den samme håndfuld af mønstre alle sammen og sætter dem på hovedet og på tværs [...] det bliver bare sådan noget: Land, jord, land, jord og så hav. Altså de kan ikke skrive sproget. De bruger bare mønstrene vilkårligt, og så sætter de havværktøjer på landlinjen og sådan nogle ting [...] Inuittatoveringer er stammetatoveringer, så dem får du for gruppen [...] Men hvorfor har kvinden alle de her fangstredskaber, når det ikke er hende der bruger dem, men det har hun for at skabe balancen mellem de her to verdner, det er sagt til mig mange gange af ældre, at det er kvinden som fanger dyrene, det er bare manden som kaste harpunen (informant 3).

Informant 3 er ikke selv en del af modebranchen, men derimod involveret i revitaliseringen af inuit-tatoveringer. Informanten har derfor en holdning til, hvordan mønstrene fra inuitiske tatovering bliver anvendt både som faktiske tatoveringer og som remedieringer på eks. tekstiler. Den konkrete placering af symboler på kroppen har spillet og spiller stadig en stor rolle for de personer, som anser tatoveringer som amuletter, fordi tatoveringernes formål var at opretholde balancen mellem den synlige og usynlige verden (Hansen, Meldgaard \& Nordquist 1992, 111-14; Krutak 2014, 24, 35). Dette er imidlertid ikke nær så vigtigt for modeskaberne og designerne, og disses brug af de traditionelle symboler som grafiske elementer i deres design er dermed et tydeligt eksempel på, at traditionen bliver fortolket og tilpasset en nutidig kontekst.

Vores design hylder individualismen og kvinder, der tør stole på sig selv og klæde sig efter deres egen mavefornemmelse snarere end at forsøge at passe ind i mængden (Nickie Isaksen, Isaksen Design, til Suluk 2019 nr 1).

På trods af den umiddelbare forskel mellem inuitisk tatoveringspraksis og remedieringen af tatoveringer i modebranchen ønsker begge parter at udtrykke et fælles mål, nemlig at promovere en stærk moderne kvinderolle i Arktis. Forskellen består derfor mere i udgangspunktet, nemlig spørgsmålet om, hvorvidt denne kvinderolle har sin rod i kollektivet eller i individualismen.

Foruden i modebranchen spiller inuitisk tradition og trosforestillinger også en rolle hos forskellige hudplejeproducenter som blandt andre Inuacare og Inuitcare, begge miljøbevidste og økologiske hudplejeproducenter, der henter deres råvarer i den grønlandske natur. Dette kan man blandt andet læse på Inuacares hjemmeside:

Det samme gælder visionen: at tilbyde et unisex økologisk brand, som er 100\% hjemmehørende i Grønland, baseret på vildtvoksende, lindrende og plejende urter og planter helt i tråd med den grønlandske, kulturelle tankegang om bæredygtighed (Inuacare).

Hudplejeproducenterne bygger her videre på den udbredte animismetanke fra inuitisk religion på en måde, der fint hænger sammen med globale tendenser om økologi og bæredygtighed.

Inuitiske traditioner spiller også en rolle i populærmusik (Otte 2015, 114). Dette ses både i forhold til instrumentering, rytme, tekst og sceneshow ved liveperformances. Den grønlandske tromme, qillat, var inuitternes eneste musikinstrument og blev første gang i en moderne kontekst anvendt af rockbandet Sume i 1970'erne (ibid. 129; Pedersen 2014, 51). I dag bruges den i populærmusik af populære grønlandske bands som Nanook og Small Time Giants. Den karakteristiske rytme i den traditionelle tromme- 
dans og variationer af frasen Aajai ja aai aajaa aa, ligeledes en traditionel del af trommedansen, bruges som intro til numre som f.eks. Small Time Giants' "We are the Arctic" (Small Time Giants 2015) og Nanooks "Kisimiinneq" (Nanook 2009). I musikvideoer og til koncerter vil trommedanseren desuden optræde iført traditionel klædedragt og grønlandske amuletter. Tekstmæssigt fylder den inuitiske mytologi også meget i nogle sange, blandt andet i Nanooks "Pileritooq" (Nanook 2014) og "Aarnuaq (Talisman)" (Nanook 2018), der handler om inuitternes styrke og talismaners magi på slæderejser. Mytologien kommer stærkest til udtryk i Nanooks samarbejde med Selvstyrets miljøkampagne i 2014, hvor sangen "Sassuma Arnaa" formidler en genfortolkning af den oprindelige myte om Havets Moder (Nanook 2014). I musikvideoen er det imidlertid ikke menneskets tabubrud, men henkastning af affald i havet, som forhindrer fangstlykken. Nanooks genfortolkning af Havets Moder er således et tydeligt eksempel på en reaktualisering af en gammel myte via tilpasning til nutidige problemstillinger, samtidig med at mytens adfærdsregulerende funktion bevares. I dag handler det blot om ikke at smide affald i naturen (Sinding Jensen \& Geertz 1991, 19, 22; Geertz 1993, 334).

Eksemplerne fremhævet idet ovenstående - modebranchen, hudplejeprodukter, og musikscenen - er alle eksempler på en øget interesse for den gamle kultur og dennes traditioner. Der er imidlertid stor forskel på interesse for og anvendelse af oprindelige religiøse motiver og så en decideret praktisering af traditioner og trosforestillinger fra inuitisk religion som en genoptagelse eller fortsættelse af den gamle tradition. Man kan derfor med rette betegne mainstream-revitaliseringstendensen som en primært kulturel revitalisering - mere end en egentlig religiøs revitalisering (Paldam 2017; 143 Pedersen 2014, 53) Dette fremgår også tydeligt af forholdet til den oprindelige tradition, idet eksponenterne for mainstream-revitaliseringen i høj grad udvælger og tilpasser elementer fra traditionen på en måde, som giver mening for nulevende inuitter og grønlændere.

\section{Revitalisering som nichetendens - hvad er det, og hvor finder vi den}

I det følgende afsnit vil jeg belyse revitaliseringen som nichetendens, herunder trommesang og -dans, traditionelle tatoveringer og storytelling. I modsætning til mainstreamtendenserne er revitaliseringens nichetendenser langt mindre udbredte, både geografisk og i antal praktiserende. Til gengæld er revitaliseringen som nichetendens mere dybdegående og velovervejet for de mennesker, som tager del i den.

I de seneste to årtier er interessen for den oprindelige trommedans steget voldsomt i Vestgrønland, hvor den ellers gradvist forsvandt efter missionæren Hans Egedes ankomst til Grønland i 1721 (Pedersen 2014, 52). Trommedansen har imidlertid været bevaret både i Nordgrønland og Østgrønland. Den øgede interesse kan blandt andet ses gennem stiftelsen af trommedanserforeningen "Inngertartuti" i Nuuk i 2010 og qillat-seminariet i Kulturhuset i Nuuk i 2014 med repræsentanter fra forskellige inuitiske nationer (Schmidt 2012, 57; Mønster 2015, 57; Lyberth 2015, 25). 
De trommedansere, jeg har talt med i forbindelse med projektet, har vidt forskelligt forhold til trommedans som henholdsvis kulturelt og religiøst fænomen (ibid. 50). Denne diversitet fremgår blandt andet i forhold til informanternes forskellige opfattelsen af sig selv som enten kulturformidlere eller individer, som dyrker trommedans som en del af deres religiøse praksis:

Vi samler vores sange. Vi indsamler nu både vestgrønlandske, Qaanaaq [Nordgrønland] og østgrønlandske og dem skriver vi ned. [...] Når vi hører en ny, altså en gammel ny trommesang, så vil vi gerne vide, hvordan den er bygget, op og hvordan den er lavet. [...] Hvis der kommer en ny sang, så prøver vi at finde ud af det (informant 2).

Den pågældende informant udtrykker her et ønske om at indsamle og bevare de gamle trommesange om viden om deres oprindelse og historie. Informanten ønsker at bevare og dokumentere så meget som muligt af traditionen for eftertidens generationer. Den pågældende informant tilhører således den gruppering af trommedansere, som primært anser sig selv som kulturformidlere, der ønsker at gøre trommesangene relevante i nutiden og en del af hverdagen for alle i Grønland:

Det er kulturelt, det betyder meget for identiteten. Og det er vores forfædres eneste musikinstrument, og trommen skal vi ikke bare glemme, og den skal ikke bare hænge på nationalmuset eller andre museer eller derhjemme, den skal vi tage og bruge (informant 2).

Informanten giver her også udtryk for kulturformidlingen som en del af den kulturelle identitet, som er under konstant udvikling i Grønland, og som gamle inuitiske traditioner udgør en stadig større del af. Der er således også tale om en kollektivt orienteret praktisering af trommedansen frem for en mere individuel. Dette er en tilgang, som informanten deler med Grønlands Nationalteater og skuespillerskolen:

I dag er teatret en uafhængig, offentlig institution med det formål at skabe forestillinger inspireret af den grønlandske kultur [...] skolen [lægger] også vægt på et varieret spektrum af scenekunst med bl.a. grønlandsk maskedans, sang, dans og klovneri (Grønlands Nationalteater).

Som studerende på skuespillerskolen lærer du om at arbejde på grundlag af en bred indsigt i kulturhistorien og med særlig vægt på inuits historie (Skuespillerskolen).

Informant 2 understreger, at den grønlandske tromme både kan og har kunnet anvendes til mange forskellige ting fra underholdning til personlige religiøse behov. Direkte adspurgt om trommen som religiøst redskab til at skabe kontakt med inuitiske forfædre understreger han, at han ikke selv tror på en sådan mulighed:

Jeg kender nogen, som tror, at man har kontakt i gang, når man bruger trommen. Men vi er forskellige fra person til person. Og jeg selv gør ikke det (informant 2).

Selvom informanten selv primært anvender trommen til kulturelle formål, understreger han samtidig, at han har kendskab til andre, som anvender trommedansen med det religiøse formål at kontakte inuitiske forfædre. Dette beskriver informant 1 her:

Det er sådan, at jeg er en udvalgt af min forfædre, så jeg kan formidle og fortælle om vores egen kultur især vores grønlandske tromme [...] jeg bruger den mest til åndelige og spirituelle ting (informant 1). 
Informanten fortæller, at han er udvalgt af sine forfædre til at udføre bestemte opgaver i sit liv vedrørende formidling og praktisering af inuitiske trosforestillinger. Senere fremhæver han, at han kan bruge trommen til at kontakte forfædrene for at få råd og vejledning, men at dette også kan lade sig gøre uden trommen. I den inuitiske kosmologi bor de døde enten i over- eller underverden. Der findes myter, som beskriver åndemaneres rejse til de dødes verdner (Rasmussen 1978, bind 172-8), men trommedansens primære rituelle funktion var at hidkalde åndemanerens hjælpeånder, og ikke forfædrenes ånder (ibid. Bind 1 16, bind 2 31). Når informanterne anvender trommen som redskab til at kontakte deres forfædre, er der således tale om en innovation i trommedansens revitalisering, som ikke er en kontinuitet med traditionen. Dette faktum peger i retningen af, at informantens praksis tager sit udgangspunkt i, hvad der er rigtigt for individet selv, snarer end den kollektive tradition.

Nå jeg spiller trommedans/-sang så spiller jeg det ikke på nordgrønlandsk og heller ikke på sydgrønlandsk, jeg spiller det på min måde (informant 1)

Informanten fremhæver desuden, at trommesangene også har healende egenskaber:

Hun lå på gulvet og jeg spillede for hende i 20 min [...] Og så da vi var færdige, så sad vi ved et bord, og hun ville snakke om, hvad hun oplevede. Og hun sagde "da du endelig begyndte at synge, så kom der noget flyvende i min tanker, og brikkerne faldt på plads" [...] Og da jeg var ung, har jeg altid ikke kunne lide min stemme, men det er den, der kan heale (informant 1 ).

Det samme er tilfælde for den moderne åndemaner Robert E. Perry II, også kendt som Hivshu, som i sin bog Vores forfædre med shamaner beskriver forholdet mellem trommedansen og forfædrene således:

Ved at slå på trommen giver vi liv til vores forfædre, ligesom vi giver os chancen for at leve og give vores efterkommere livet også (Peary II, 2016, 31).

Både Hivshu og informant 1 anser således trommedansen for at være et religiøst hjælpemiddel til at kontakte inuitiske forfædre med det formål at opnå hjælp i deres eget liv. Udover at være trommedansere betegner de også begge sig selv som storytellere, hvilket indebærer en særlig forpligtelse til at formidle inuitternes religion til andre.

Jeg er trommedanser og så er jeg sådan en storyteller, men den titel fik jeg først i sommers

i Barrow i Alaska. Fordi en shaman eller en storyteller kan ikke kalde sig selv for det. Det er en anden, der skal kalde en for det (informant 1).

Af et tidligere citat fremgår det, at informant 1 føler sig udvalgt af sine forfædre til at formidle inuitternes religion og tradition i form af trommedanse og sange og ved at fortælle de gamle sagn og myter. Af ovenstående citat fremgår det desuden, at man ikke selv kan udnævne sig til storyteller, men at det er en titel, som kun andre storytellere kan give videre. Erhvervelsen af titlen som storyteller får dermed karakter af en slags indvielsesrite, hvilket er yderst interessant i betragtning af den i øvrigt nærmest ikkeeksisterende institutionalisering inden for revitaliseringsprocessen. Der er intet i mit feltarbejde, der peger på en egentlig institution bag revitaliseringen eller en samlet organisering af processens forskellige aktører. Der er snarere tale om uafhængige ini- 
tiativer i et løst forbundet netværk. Blandt de moderne åndemanere kan også fremhæves Angaangaq og hans projekt IceWisdom. Angaangaq betegner i lighed med de øvrige sig selv som grønlandsk shaman, healer, storyteller og trommedanser. Angaangaq er involveret i forskellige projekter i Grønland og udlandet. Det største projekt i Grønland drejer sig om ønsket om at etablere et healingcenter nær Kangerlussuaq på Grønlands vestkyst:

Aanakasaap Illua wants to make native traditions, ceremonies and ancient healing knowledge accessible [...] Traditional healing methods like mud baths, sweat lodges, spiritual walks and ceremonies will be utilized (IceWisdom).

Angaangaq ønsker således at etablere et healingcenter, hvor traditionelle healingmetoder praktiseres. Det fremgår imidlertid ikke entydigt, hvori disse behandlingsmetoder består, og om de udelukkende er baseret på inuitisk tradition. I sin beskrivelse af sig selv tydeliggør Angaangaq dog sin slægts tilhørsforhold til "traditional healers of the far North", hvilket indikerer, at han selv anser denne relation for vigtig. I denne undersøgelse har jeg fremhævet Hivshu og Anagaagaq som eksempler på moderne åndemanere, men der findes flere, f.eks. Maannguaq Berthelsen og Angajoq Nattoralissuaq (Lyberth 2015, 38. 50; Thisted 2018, 275).

Informanterne fra trommedansermiljøet og de moderne shamaner er generelt enige om, at det er vigtigt at huske fortiden, og hvor man kommer fra. De fremhæver også alle, at trommesang og -dans er en vigtig del af en ny, voksende, kulturel identitet i Grønland. Uenigheden opstår i forhold til, om man primært anser sig selv for kulturformidler eller religiøs praktiker og storyteller.

Udover tromme- og maskedans og storytelling har man også set en stor genopblomstring af traditionelle, inuitiske tatoveringer i Grønland, særligt inden for de sidste to år. I lighed med trommedanserne beskriver informanten fra tatovørbranchen tatoveringerne som udtryk for en kollektiv kulturel identitet, som er på vej tilbage, og som binder folk sammen:

Det hele er tilbage til åndetroen [...] Alt har jo sjæl, det er jo det første skridt [for] at forstå, hvad vi gør, det er, at alt har sjæl. Trommedansen er taget op igen, strubesang er taget op igen, maskedans er taget op igen. Selv det at bruge en qulo altså selve lampen er jo taget op igen, og man går mere og mere væk fra den her ikonisering af de forskellige kulturobjekter - og rent faktisk at bruge dem [...] Når man tager en prækolonialpraksis op og genopliver den, så vil det altid være identitetsarbejde [...] Jeg tror, at folk de gerne vil sige, at jeg er grønlandsk, og jeg er inuk, og de er stolte af det (informant 3).

Informanten beskriver her, hvordan tatoveringerne både bliver udtryk for, hvem ejermanden er, og hvad personen er en del af. Tatoveringerne signalerer et bestemt tilhørsforhold til den inuitiske kultur og beskriver således både en individuel og kollektiv identitet (Krutak 2014, 56-63). På den måde bliver tatoveringerne, ligesom i fortiden, et diakritisk tegn, som afgrænser én gruppering fra andre. Tatoveringerne er ikke kun et udtryk for kulturel identitet, for informanten beskriver tatoveringerne som amuletter, hvis betydning er knyttet til trosforestillingerne i inuitisk religion:

Så når vi ser på eks. tatoveringerne med det kristne sind, så forstår vi ikke hvorfor $\mathrm{Y}$ ikke kan vende den vej. Men det forstår vi, når vi ved, at det er, fordi den har sjæl, og den 
hører til vandet, og vandet hører til Sassuma Arnaa [Havets Moder] og hun er havets sjæl, og hun hader land, så du kan ikke have en harpun, der står oppe på land, det går bare ikke (informant 3 )

Amuletterne er forbundet med animismetanken og har til formål at opretholde balancen mellem den synlige og den usynlige verden. Derfor er det også vigtigt for informanterne, at tatoveringerne udføres korrekt og i overensstemmelse med de oprindelige mønstre, som de baserer på etnografiske fotos fra Canada, Alaska og Østgrønland samt arkæologiske fund. Som det fremgår af nedenstående citat, er den korrekte udførelse imidlertid ikke begrænset til tatoveringspraksis, men strækker sig ud i informanterne øvrige liv:

Lige såvel som, at den ulo jeg bruger til fisk, den bruger ikke også til rensdyr. Jeg holder tingene adskilt og lægger dem på forskellige tallerkner. Det er de balanceakter, vi gør i vores hverdag, som er de 500 tabu, som bliver forklaret gennem de her 2000 myter. Som jo forklarer præcis, hvad du skal gøre, og hvordan du skal gøre det, og hvad der sker, hvis du ikke gør det, og hvordan du reparerer det (informant 3)

Informanten praktiserer således inuitisk religion og tradition i sin dagligdag og i en moderne kontekst. Det er dermed også absolut nødvendigt for informanten at have et solidt kendskab til de gamle myter og trosforestillinger. For informanten er religionen ikke begrænset til tatoveringer, omend det er meget centralt i informantens praksis. Informanterne beskriver de traditionelle tatoveringsmetoder såsom skin stitching og hand poking som værende centrale (Krutak 2014, 29-30). De traditionelle metoder er moderniseret i dag, sådan at de opfylder moderne sterile standarder, og fortrækkes frem for elektriske tatoveringsmakiner. Informanten beskriver også forskellen mellem vestlige tatoveringer, oprindelige inuitiske tatoveringsmønstre og neoinuitiske mønstre:

Vestlige tatoveringer dem får du for jeget. Inuittatoveringer er stammetatoveringer, så dem får du for gruppen. Og du ændrer ikke tatoveringerne, så de passer til din historie (informant 3).

Informanten understreger flere gange, at de inuitiske tatoveringer er en kollektivkultur, som udvikles og forandres langsomt og i fællesskab. Derfor mener informanten ikke, at mønstrene må tilpasses enkelte individer, da de er udtryk for et kollektiv og ikke et individ. Det er således tydeligt, at den direkte linje mellem traditionen og nutidig praksis er helt central både i forhold til korrekt udførelse og grafisk udtryk.

På trods af at nichetendensen er repræsenteret af et relativt lille antal individer, forekommer der stadig interne variationer iblandt dem. Den primær uenighed omhandler hvorvidt de inuitiske traditioner i dag skal opfattes som religiøse eller blot kulturelle handlinger. Endvidere opstår der uenighed om, i hvilken grad traditionen skal ses som autoritativ, eller kan fortolkes og tilpasses forskellige individers behov. På den måde forekommer der to grupperinger, hvoraf den ene primært reproducerer kulturarv for at genskabe en kollektiv kulturel identitet, mens den anden tilpasser kulturarven individuelle behov. 
På baggrund af kortlægningen af revitalisering som henholdsvis mainstreamtendens og nichetendens samt disse karakteristika præsenteres her en model til forståelse af revitaliseringstendensen grupperinger:

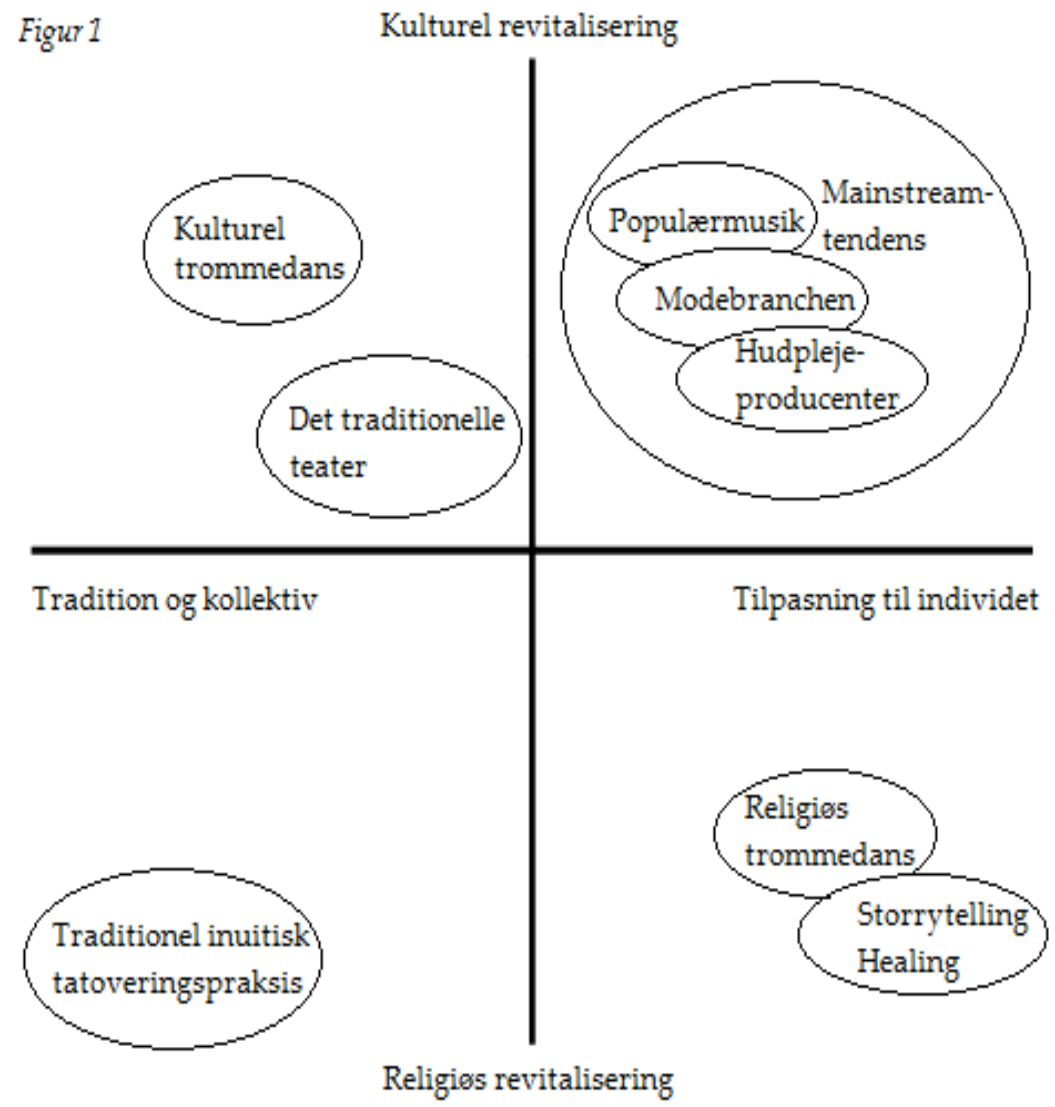

Figur 1: Revitaliseringsprocessen i Grønland og Danmark kan inddeles i fire hovedgrupper, alt efter hoordan de forholder sig til tradition, kultur, religion, individ og kollektiv. Grupperne placeret øverst $i$ højre hjørne tilhører alle revitaliseringens mainstreamtendens, men de øvrige felter viser variationer inden for revitaliseringens nichetendens.

Forskellene imellem revitaliseringens mainstream- og nichetendens kommer til udtryk på to måder: 1) opfattelsen af inuitisk tradition som enten kultur eller religion og 2) antallet af mennesker, som tilhører tendensen. Der er desuden stor forskel på, hvor revitaliseringen finder sted. Mainstreamtendensen har bredt sig ud over hele Grønland og blandt den grønlandske befolkning i Danmark. Nichetendensen spredes derimod langsomt og er centreret omkring Nuuk og Danmark. Den langsommere spredning skyldes sandsynligvis, at deltagelse i nichetendens er langt mere forpligtende, end det er tilfældet i mainstreamtendensen. Der er stor forskel på forpligtelsesgraden mellem at iføre sig en kjole med tatoveringsmotiver og at få inuitiske mønstre tatoveret 
på huden, især i ansigtet. Som tidligere nævnt fungerede de oprindelige, inuitiske tatoveringer som diakritiske tegn, som tilkendegav kulturelt og geografisk tilhørsforhold. Det samme er tilfældet i dag, både med de faktiske tatoveringer og de grafiske remedieringer i form af tøj og smykker. De faktiske tatoveringer kommunikerer et permanent og til alle tider gældende tilhørsforhold til den inuitiske etnicitet, hvorimod modebranchens produkter kommunikerer et situationelt etnicitetsforhold, som kan ændres og tilpasset efter kontekst og behov. Det er ligeledes langt mere forpligtende og tidskrævende at tillære sig kulturel og religiøs trommedans end at anvende elementer herfra i moderne populærmusik, hvorfor den form for trommedans i højere grad definerer udøverens etniske tilhørsforhold.

Revitaliseringens tilknytning til opbyggelse og definition af den inuitiske etnicitet kan være en vigtig del af forklaringen på, at nichetendensen geografisk er koncentreret omkring Nuuk og Danmark. Der hersker i forskningsverden stor uenighed om den præcise definition af begrebet etnicitet. De fleste er enige om, at etnicitet betegner et socialt organiseringsværktøj, men er uenige om, hvordan grupperinger og særligt deres grænser konstitueres. Men denne problematik ikke er begrænset til en akademisk diskussion, men faktisk beskriver selve kernen i den konstante forhandling af etnicitet, som den praktiseres af etnicitetsmedlemmerne (Paldam 2017, 103). Etnicitet formuleres primært i modsætningspar. En gruppe individer i et konkret eller forestillet fællesskab definerer sig i forhold til andre som henholdsvis ingroup og outgroup. Det er således i mødet med andre, at etnicitetens rammer dannes og ændres (Barth 1998, 15). Revitaliseringsprocessens nichetendens, den del af revitaliseringsprocessen som tydeligst udtrykker etnisk tilhørsforhold, findes derfor primært i de geografiske områder, hvor kontakten til det globale samfund og særligt den tidligere kolonimagt, Danmark, er mest udtalt:

Folk, der står med et ben i begge lejre, de kan have et enormt behov for at hægte deres identitet fast på noget, der ubetinget er inuitisk. [...] det jo damer på 50 år og opefter, skoleinspektører og borgmestre osv. veluddannede kvinder med en sikkerhed i sig selv og en dygtighed, men som måske lige som mig har gået igennem en stærk danisering (informant 3).

Revitaliseringen ses således tydeligst i de områder, hvor kulturkløfter og identitetskriser er meste udbredte. En fangerkone i Nordgrønland har ikke behov for en tatovering, som viser, at hun tilhører en etnisk fangekultur, for hun praktiserer denne kultur hver eneste dag og lever i et samfund, som i høj grad er monokulturelt. Inuit i Nuuk og Danmark befinder sig imidlertid i et flerkulturelt samfund og varetager ofte arbejdsopgaver, som ligger langt fra de traditionelle inuitiske erhverv. Derfor kan inuit bosat i Nuuk og Danmark føle et større behov for at udtrykke deres etniske tilhørsforhold eksplicit ved at deltage i revitaliseringsprocessen. 


\section{Etnopartikulær nichereligion eller inuitisk inspireret New Age- tendens med globalt udsyn}

Grupperingerne blandt af udøvere af inuitisk religion og kultur forholder sig forskelligt til spørgsmål om tradition, ortopraksi og hvem som kan og bør være en del af revitaliseringsprocessen. De to nederste grupperinger i figur 1 adskiller sig således markant i deres tilgang til tradition og tilpasning, hvor den ene primært kan betegnes som etnopartikular nichereligion med blik for det inuitiske samfund, og det andet som inuitisk inspireret New Age-tendens med globalt udsyn.

Forskellen mellem de to grupperinger kommer til udtryk gennem deres fortolkning af mytologiske forestillinger og relationen til andre religioner. Den etnopartikulære nichereligions mytologi er baseret på et dybdegående studium af historiske og etnografiske beskrivelser fra hele Arktis med kraftig frasortering af, hvad, de mener, er vestligt prægede fortolkninger og tilpasninger. 'Den inuitiske New Age-tendens' er derimod præget af en del synkretistiske forestillinger baseret på inuitiske myter og kristendom:

\footnotetext{
Jeg mener ikke, at kristendommen er farlig for trommen. Og trommen er heller ikke farlig for kristendommen. Der er mange, der siger - hey du har to tro, men for mig, så nej, jeg har kun én [...] jeg beder ikke til himlen, jeg beder til mine forfædre, fordi de videregiver min bøn til ham, eller den der bestemmer over os (informant 1).

The drumming is the heart talking and the songs are from the univers giving to you to be connected to your ancestors and descendants who are close to the creator (Hivshu).
}

Begge informanter udtrykker i de ovenstående citater en forbindelse mellem deres personlige inuitiske forfædre og en overordnet guddom inspireret af kristendommen. Forfædrene indtager en mediatorfunktion, hvorigennem de varetager informanternes interesser i forhold til den overordnede guddom (Lyberth 2015, 36; Thisted 2008, 40). Informanterne er bevidste om denne sammenblanding mellem inuitiske og kristne trosforestillinger, men anser det ikke for problematisk (Oosten, Laugrand \& Remie 2006, 467; Lyberth 2015, 66). Udover de synkretistiske elementer i trosforestillingerne er 'inuitisk inspireret New Age' også kendetegnet ved en generel orientering mod det globale samfund. IceWisdoms hjemmeside findes således på både engelsk, tysk og italiensk, og Hivshus hjemmeside er ligeledes på engelsk; begge er endvidere bosat i udlandet. Desuden henvender de sig begge til et bredt publikum fra forskellige lande, kulturer og religioner, som alle er velkomne til at deltage i deres arrangementer:

IceWisdom International is committed to preserving Mother Earth and all who live on her, by creating Healing Circles [...] The Elders teach us if we return to harmony in our lives, melting the ice in our hearts, reconnecting with one another, we will survive. It is time to use this knowledge to help mankind (IceWisdom).

Angaangaq fra IceWisdom er endvidere i kontakt med mange forskellige kulturer og besøger forskellige folk og religiøse ledere fra hele verden, deriblandt paven. Den inuitisk inspirerede New Age-tendens er således rettet mod den globale verden, hvorimod den etnopartikulære nichereligion er orienteret imod en etnisk begrænset gruppe individer: 
Vi er imod, at vores tatoveringer skal ende op i den vestlige branche. Vi er kun 150000 inuit $i$ verden, så meget hurtigt ville der være flere ikke-inuit i verden som havde de her tatoveringer [...] derfor beskytter vi dem, tatoveringerne, 'sproget' blandt inuit er så nyt, vi er først ved at lære, hvor meget vi har mistet, vi skal lige have tid til at bearbejde den sorg og det tab af kultur, pludselig så får inuitkvinden en rolle, som er vældig stærk (informant 3).

Informanten, som er involveret i revitaliseringsprocessen omkring inuitiske tatoveringer, understreger, at man i branchen omkring traditionel tatovering ønsker at begrænse udbredelsen af inuitiske tatoveringer til medlemmer af den inuitiske etnicitet. Dette skyldes blandt andet, at de ønsker tid til selv at genoprette deres kulturelle identitet. De personer, som får inuitiske tatoveringer, skal derfor have en tilknytning til den inuitiske etnicitet:

Vi dyrker ikke nationalitet inden for inuittatoveringer. Det kan være folk, som er født og opvoksede i Danmark og er rødhårede og har blå øjne og ikke har en fløjtende fis med dagligdagen i Grønland at gøre, men de har noget med den grønlandske befolkning i Danmark at gøre [...] Resten af inuitbefolkningen i verden, udover dem som har tilknytning til Danmark, de har jo et kort, hvor der står Eskimo på, og ud fra det så står der en blodprocent med, hvor meget inuk de er [...] Vi behøver ikke en blodprøve af folk (informant 3).

Etnicitetsforståelsen i den etnopartikulære nichereligion er ikke decideret blodsbestemt, og det er uklart, hvilke præcise kriterier der gør en person til inuk. Informanten tager afstand fra den kvantitative blodprocentsetnicitetsinddeling, men fællesskabet er alligevel begrænset til de individer, som har en vis grad af genetisk og kulturel tilknytning til den inuitiske befolkning. I den henseende er etnicitetens grænser både bestemt af arv og miljø.

\section{Konklusion}

På baggrund af analysen af det indsamlede kvalitative materiale tillige med digitalt materiale fra internettet kan revitaliseringen af inuitisk religion og tradition i Grønland beskrives som en tendens, der stikker i mange forskellige retninger. Overordnet kan tendensen inddeles i to hovedtyper, mainstream- og nichetendens, hvor udbredelse og forholdet til den oprindelige tradition er varierende. For begge tendenser gælder det, at de er karakteriseret ved en lav grad af institutionalisering og organisering. De forskellige grupperinger forholder sig vidt forskelligt til tradition, tilpasning, kultur og religion. Således opfatter nogle grupperinger primært deres praksis som kulturel, men andre beskriver den som religiøs. Desuden fremstår der en forskel i informanternes målgrupper, som tydeliggør om i grupperne er etnopartikulære eller globalt indstillet.

\section{LITTERATUR}

Barth, Fredrik

1998 Ethnic Groups and Boundaries: The Social Organization of Cultural Difference, 
London: Waveland Press, 5-38.

Fonda, Marc

2012 "Canadian Census Figures on Aboriginal Spiritual Preference - A

Revitalization Movement?", Religious Studies and Theology 30/2, 169-185.

https://doi.org/10.1558/rsth.v30i2.171

Geertz, Armin W.

1993 "Theories on tradition and change in sociology, anthropology, history and the history of religions" in Luther Martin \& Jacques Wardenburg, eds., Religious Transformations and Socio-Political Change (Religion and Society 33), Berlin: De Gruyter, 323-348. https://doi.org/10.1515/9783110884203.323.

Geertz, Armin W. \& Jeppe Sinding Jensen

1991 "Tradition and Renewal in the History of Religions: Some Observations and Reflections" in Religion, Tradition and Renewal, Aarhus: Aarhus University Press, 13-27.

Hansen, Jens Peder Hart, Jørgen Meldgaard \& Jørgen Nordquist

1992 Qilakitsoq-De grønlandske mumier fra 1400-tallet, 2. Udgave, 1. Oplag,

Grønlands Landsmuseum, København: Christian Ejlers' Forlag.

Kleivan, Inge \& Birgitte Sonne

1985 "Introduction", in Th P. van Baaren et. al. eds. Eskimos: Greenland and Canada (Iconography of Religions), Leiden: E.J. Brill, 1-33.

Krutak, Lars

2014 Tattoo Traditions of Native North America - Ancient and Contemporary Expressions of Identity, Arnheim: Stichting LM Publishers.

Lundager Jensen, Hans J.

2013 "Robert Bellah, religion og menneskelig evolution", Religionsvidenskabeligt Tidsskrift 60, 11-31. https://doi.org/10.7146/rt.v0i60.20408

Lyberth, Juaaka

2015 Grønlandske før-kristne trosforestillinger i nutiden - Synkretistiske trostræk og tendenser $i$ det nyreligiøse felt $i$ Grønland, Specialeafhandling, Institut for Eskimologi og Arktiske studier, Københavns Universitet.

Mønster, Trine Bondo

2015 Havets moder og Hans Egede - En religionsvidenskabelig analyse af levn fra inuitisk religion og deres sameksistens med kristendommen i det moderne Grønland, Specialeafhandling, Religionsvidenskab, Aarhus Universitet

Oosten, Jarich, Frédéric Laugrand \& Conelius Remie

2006 "Perception or Decline: Inuit Shamanism in the Canadian Arctic", Etnohistory 53/3, 445-477. https://doi.org/10.1215/00141801-2006-001

Otte, Andreas

2015 "Nuuk underground musical change and cosmopolitan nationalism in Greenland", Popular Music 34/1, 113-133.

https://doi.org/10.1017/S0261143014000713

Paldam, Ella

2017 Contemporary Chumash religion - The Revitalisation of Indigenous Tradition in 
Native California, ph.d.-afhandling, Aarhus Universitet.

Peary II, Robert E.

2016 Vores forfxedre med shamaner, 1. Udgave, 1 oplag af Mananuup Atuakkiorfia

Pedersen, Birgit Kleist

2014 "Kulturel revitalisering - hvorfor?", Grønlandsk kultur og samfundsforskning 2013-14.

Qvist, Niels Ole

2019 "Stærke kvinder med stil", Suluk 1.

Rasmussen, Knud

1925 Fra Grønland til Stillehavet, bind 1, København: Nordisk Forlag.

1978 Myter og sagn fra Grønland, bind 1 og 2, Nordiske landes bogforlag, fotografisk genoptryk af original fra 1921.

Schmidt, Christine Marie

2012 Gammel religiøsitet $i$ en moderne verden - en religionsvidenskabelig analyse af hvorvidt religiøse og kulturelle træk fra deres førkristne tradition, specialeafhandling, Religionsvidenskab, Aarhus Universitet.

Thisted, Kirsten

2018 "Åndernes kraft og Kristendom" in: Svend Rune Havsten et al., Kristendom $i$ Grønland - Religion, kultur og samfund - En mosaik, København: Eksistensen, 250-284.

2008 "Åndernes kraft og kristendom - fire film om inuitisk religion", Religion Tidsskrift for Religionslærerforeningen for Gymnasiet og HF, 26-50.

Wallace, Anthony

1956 "Revitalisation Movement", American Antropologist 58/2, 264-281. https://doi.org/10.1525/aa.1956.58.2.02a00040

Offentligt tilgængeligt analysemateriale

Angakkorsuaq, Angaangaq

2019 https://icewisdom.com (set 15/9 2019)

Berthelsen, Louise Lynge

2018 https://www.nuukcouture.com/ (set 15/9 2019)

Chemnitz, Bibi

2019 https://www.bibichemnitz.com/pAge/about-us (set 15/9 2019)

Grønlands nationalteater:

2019: http://qeqqa.gl/groenlands-nationalteater/

Isaksen, Rita \& Isaksen, Nickie

58 Sidse Birk Johannsen 
Jakobsen, Maja Sialuk

2019 https://www.facebook.com/inuittattootraditions/(set 15/9 2019)

Nielsen, Anne Mette Koustrup \& Nielsen, Pipaluk

2019 https://www.instagram.com/inuacare/?hl=da (set 15/9 2019)

2019 https://inuacare.com/om-os/_(set 15/9 2019)

Peary II, Robert E. (aka. Hivshu)

2019 http://hivshu.com (set 15/9 2019)

Skuespillerskolen:

2019: https://sunngu.gl/da/Erhvervsuddannelse/Studieretninger/Kunst-ogKultur/Skuespilleruddannelsen_(set 15/9 2019)

Small Time Giants (Jensen, Miki \& Hammeken, Pilu \& Skovaa, Jakob \& Nilsson, Jonas)

2019 https://www.musixmatch.com/lyrics/Small-Time-Giants/We-are-the-Arctic $\underline{(\text { set } 15 / 92019)}$

\section{Nanook (ukendt oversætter)}

2019 https://lyricstranslate.com/en/pileritooq-passionate.html_set 15/9 2019)

2019 https://lyricstranslate.com/en/sassuma-arnaa-mother-sea.html (set 15/9 2019)

Sidse Birk Johannsen, religionslærer, cand. mag. GUX Aasiaat, Grønland 